\title{
Aneta Stawiszyńska
}

Łódź

anetas83@wp.pl

\section{Zorganizowane wyjazdy na wieś jako forma pomocy dzieciom lódzkim w latach I wojny światowej}

Wybuch pierwszej wojny światowej, będący końcem pomyślnego rozwoju Łodzi, odcisnął ogromne piętno na życiu mieszkańców miasta. Zapaść gospodarcza pociągająca za sobą zjawiska takie jak bezrobocie, przyczyniła się do niespotykanej wcześniej biedy, która w dużej mierze dotyczyła miejscowych dzieci ${ }^{1}$. Ubóstwo i poważne niedożywienie miały negatywny wpływ na kondycję zdrowotną najmłodszych łodzian. Badania lekarskie przeprowadzane w 1916 r. w szkołach wykazały, że statystycznie jedynie ok. 25\% łódzkich dzieci cieszyło się dobrym zdrowiem.

Tabela 1. Stan zdrowia dzieci łódzkich w 1916 r.

\begin{tabular}{|c|c|c|c|}
\hline Szkoly & Dobry & Średni & Zly \\
\hline niemieckie & $32,8 \%$ & $53,9 \%$ & $13,3 \%$ \\
\hline polskie & $23 \%$ & $60 \%$ & $17 \%$ \\
\hline żydowskie & $22 \%$ & $69,5 \%$ & $8,4 \%$ \\
\hline
\end{tabular}

Źródło: APŁ, AmŁ, WP, sygn. 13 680, k. 214, Schulwesen.

Obok kwestii zdrowotnych czy też bytowych istotnym zagadnieniem był również brak prawidłowego nadzoru nad najmłodszymi. Problem był poważny, zwłaszcza na samym początku wojny, gdyż w związku z brakiem możliwości zapewnienia opieki, władze miasta obawiały się, by poprzez chuligańskie wybryki nie sprowokować przebywających w mieście wojsk do agresji, jak to miało miejsce w przypadku innych miast ${ }^{2}$. Miejscowa prasa często donosiła o przypadkach, np. o gromadzeniu kamieni na dachach budynków, które miały prawdopodobnie

$1 \quad$ Szerzej na temat losu dzieci łódzkich podczas I wojny światowej: A. Stawiszyńska, Realia zycia dzieci łódzkich w czasie Wielkiej Wojny. Wybrane zagadnienia, „Kultura i Wychowanie" 2014, t. VIII, s. 51-58.

2 W apelach do ludności Centralny Komitet Milicji Obywatelskiej (dalej: CKMO) przypominano m.in. wypadki drastycznych akcji odwetowych przeprowadzonych przez wojska niemieckie w Częstochowie i Kaliszu, Archiwum Państwowe w Łodzi (dalej: APŁ), Główny Komitet Obywatelski (dalej: GKO), sygn. 235, k. 3, Odezwa CKMO z dn. 19 VIII $1914 \mathrm{r}$. 
posłużyć do obrzucania wkraczających do miasta wojsk niemieckich lub też o zabawach „w wojnę" $z$ użyciem niebezpiecznych przedmiotó $w^{3}$. W tych warunkach jeden z najbardziej znanych łódzkich pedagogów, Stanisław Świdwiński ${ }^{4}$, wystosował na łamach prasy apel m.in. w sprawie zorganizowania „,kolonii szkolnych”, pozwalających choćby czasowo rozwiązać problem 5 .

Ówczesna sytuacja i ciężkie położenie miejscowych dzieci skłaniały tutejszych filantropów oraz wszelkiego rodzaju instytucje społeczne i dobroczynne do podjęcia kroków przeciwdziałających opisywanej biedzie ${ }^{6}$. Jedną z form pomocy ubogim łódzkim dzieciom było wysyłanie ich na wieś ${ }^{7}$. Należy w tym miejscu zaznaczyć, że działania te wpisywały się w panującą wtedy tendencję zachęcania miejscowej ludności do wyjazdów, zarówno letniskowych, jak i długoterminowych, związanych z podjęciem pracy w rolnictwie, gdzie łatwiej było m.in. o zaopatrzenie się w żywność. Miejscowa ludność masowo korzystała wówczas z takiej możliwości ${ }^{8}$. Działania te związane były głównie z poważnymi problemami aprowizacyjnymi z jakimi borykało się miasto 9 .

Niektórzy ze zwolenników akcji zwracali też uwagę na konieczność pokazania dzieciom przy okazji tych wyjazdów nieznanych im dotąd uroków wsi. Jak

3 „Nowy Kurier Łódzki” (dalej: NKŁ) nr 184, 14 VIII 1914, s. 2; NKŁ nr 235, 10 X 1914 , s. 3.

4 Stanisław Świdwiński - nauczyciel historii. Od 1916 r. był wykładowcą Polskiego Seminarium Nauczycielskiego w Łodzi, T. Jałmużna, Zakłady kształcenia nauczycieli w Łodzi w latach 1918-1988, Łódź 2001, s. 76.

5 W artykule $W$ palacej sprawie czytamy: „Możemy i powinniśmy skupić dzieci biedne i utworzyć dla nich »kolonie szkolne« albo choćby tylko zaopiekować się dziećmi, dając im w zamian z pożytkiem połączoną zdrową rozrywkę [...]”, „Rozwój” nr 189, 21 VIII 1914, s. 1.

6 Szerzej na temat form pomocy ubogim, A. Stawiszyńska, Lódź w latach I wojny światowej, Oświęcim 2016, s. 259-290.

7 Pierwsze kolonie letnie dla łódzkich dzieci zaczęto organizować pod koniec XIX w., m.in. przez: Łódzkie Towarzystwo Lekarskie, Oddział Łódzki Warszawskiego Towarzystwa Higienicznego, Łódzkie Chrześcijańskie Towarzystwo Dobroczynności oraz Łódzkie Żydowskie Towarzystwo Dobroczynności; w latach 1893-1912 dzieci najczęściej wysyłane były do Michałowa i Bronowic, J. Supady, Powstanie i rozwój kolonii letnich dla dzieci w Łodzi na przełomie XIX i XX wieku, „Zdrowie Publiczne” 1977, t. LXXXVIII, nr 3, s. 193-196.

8 APŁ, Akta miasta Łodzi (dalej: AmŁ), Wydział Zdrowotności Publicznej (dalej: WZP), sygn. 19 320A, k. 8, Wytyczne Wydziału Zdrowotności Publicznej z 1916 r.; H. Jabłoński, Z rozważań nad II RP. Pisma wybrane, Warszawa 1962, s. 68; A. Stawiszyńska, Łódź w latach... s. 222.

9 W związku z utrudnieniami w komunikacji do miasta nie docierały regularne transporty. Od połowy maja 1915 r. systematycznie wprowadzano system kartkowy, co i tak nie rozwiązywało problemu. Dylematem było też zmonopolizowanie niektórych, np. dostaw mąki do miasta przez niemieckie przedsiębiorstwo Wareneinfuhr. Szerzej: M.J. Szymański, Wojenny chleb (nie)powszedni. Lódź $w$ niemieckim systemie zaopatrzenia $w$ produkty $i$ surowce zbożowe na terenie okupowanego Królestwa Polskiego podczas I wojny światowej, [w:] Operacja Łódzka. Zapomniany fakt I wojny światowej, pod red. J.A. Daszyńskiej, Łódź 2011, passim. 
podkreślał w swoim artykule dr Seweryn Sterling, miało to przyczynić się do zaszczepienia u małych łodzian uczuć patriotycznych ${ }^{10}$.

Za przygotowywanie wyjazdów dzieci łódzkich na wieś odpowiadały rozmaite stowarzyszenia i organizacje działające zarówno przy administracji miejskiej, jak i stowarzyszeniach społecznych, religijnych czy miejscowych gminach wyznaniowych.

Najważniejszą organizacją zajmującą się pomocą dzieciom poprzez organizowanie dla nich wspomnianych wyjazdów była działająca przy Komitecie Obywatelskim Niesienia Pomocy Biednym ${ }^{11}$ (KONPB) Sekcja Kobiet ${ }^{12}$. Jej przedstawicielki spotykały się m.in. z delegacjami z Kutnowskiego Komitetu Ratunkowego, który oferował pomoc w zorganizowaniu stosownych miejsc. Sekcja Kobiet miała odpowiadać także za zaopatrzenie dzieci w sienniki i bieliznę pościelową. Z organizowanego przez Sekcję wyjazdu skorzystało w $1915 \mathrm{r}$. ok. 100 dzieci, które zostały wysłane do Mirosławic koło Kutna i w okolice Gostynina ${ }^{13}$. Organizacje tego oraz innych wyjazdów letnich wspierał m.in. Komitet Poznański ${ }^{14}$, który przekazał za pośrednictwem GKO 10000 mk na tenże cel.

10 Dr Seweryn Sterling w 1916 r. przekonywał: „,...] niech każde miejskie dziecko w Polsce pozna wieś polską - niech się z nią zbrata - niech mu się stanie drogiem nie podwórko, gdzie się urodziło i gdzie umrze, lecz ziemia, zlana krwią pokoleń - niech wyrośnie zdrowe pokolenie, które ukocha Ojczyznę sercem, wesprze rozumem, wzmocni mięśniami, a obroni kośćmi [...]”, Jednodniówka na dochód Wielkiej Kwesty Ogólnokrajowej „Ratujcie Dzieci”, 11 VI 1916, Łódź 1916, s. 25.

11 Komitet Obywatelski Niesienia Pomocy Biednym - przewodniczącym był pastor Rudolf Gundlach; zastępcami ks. W. Tymieniecki, W. Wolamowski oraz nadrabin Leon Treistaman. W Komitecie działały sekcje: Zbierania Ofiar, Kobiet, Opałowa, Bezdomnych, Kasa Pożyczkowo-Zapomogowa oraz Zagonków. Na potrzeby organizacyjne miasto podzielono na 20 dzielnic, we władzach których znajdowali się przedstawiciele wszystkich wyznań. KONPB roztaczał opiekę nad ok. 20 organizacjami; M. Skarżyński, Akcja pomocy społecznej w okresie działania GKO (3 VIII 1914-1 VII 1915), [w:] „Rocznik Łódzki” 1975, R. XX, s. 270.

12 Sekcja Kobiet przy KONPB - siedziba organizacji przy ul. Placowej 13. Jej przewodniczącą była baronowa Anna Heinzlowa, a członkiniami: Maria Grzybowska (wiceprzewodnicząca), Józefa Pytlasińska (wiceprzewodnicząca), Helena Hykielówna (sekretarka), Elfrieda Horak, Zofia Jarzębowska (sekretarka), Maria Horstówna, Z. Kaczyńska, Maria Libiszowska, Karolina Rokicka, Janina Śląsk, Małgorzata Szmitówna. W lipcu 1915 r. w związku z likwidacją GKO oraz mianowaniem Magistratu, organizacja podlegała Wydziałowi Dobroczynności Publicznej tegoż Magistratu; APŁ, AmŁ Wydział Prezydialny (dalej: WP), sygn. 14 025, k. 58, Pismo Sekcji Kobiet przy Wydziale Dobroczynności Publicznej do Komitetu generalnego Pomocy Ofiarom Wojny w Polsce z dn. 30 IX 1915 r., Sktad Komitetów Obywatelskich w dn. 1 V 1915 roku, Łódź, b.r.w., s. 85.

13 „Gazeta Łódzka” (dalej: GŁ) nr 150, 16 VI 1915, s. 2; GŁ nr 196, 1 VIII 1915, s. 3; NKŁ nr 188, 11 VII 1915, s. 1.

14 Poznański Komitet Niesienia Pomocy Królestwu Polskiemu - organizacja zawiązana w lutym 1915 r. Na jej czele stanął arcybiskup Edward Lisowski (po jego śmierci - Edward Dalbor). Fundusze, którymi dysponował Komitet pochodziły ze składek przekazywanych z poznańskiego, Pomorza i zagranicy. W każdym większym mieście działały komitety 
Kwalifikacje na wyjazdy odbywały się w dzielnicach KONPB. Otrzymane fundusze podzielono między dzieci chrześcijańskie i żydowskie (2/3 dla dzieci chrześcijańskich i $1 / 3$ dla żydowskich) ${ }^{15}$. W tym samym roku organizacja wysłała 120 dzieci do Rzgowa, gdzie podopiecznych oddano pod kuratelę proboszcza miejscowej parafii, ks. kanonika Macieja Skowronka ${ }^{16}$ oraz jego siostry, a także 100 dzieci do Rudy Pabianickiej, gdzie opiekę nad dziećmi roztoczyło miejscowe Koło Ziemianek pod zwierzchnictwem inżynierowej Neumanowej ${ }^{17}$. Pomimo wcześniejszego przekonania, że poza miastem łatwiej będzie zdobyć artykuły żywnościowe, latem $1915 \mathrm{r}$. sytuacja przerosła wcześniejsze założenia. Kłopoty związane z wyżywieniem podopiecznych skomplikowały się na tyle, że Sekcja Kobiet zmuszona była prosić władze miejskie o zgodę na przewóz tychże produktów dla dzieci przebywających na koloniach w Rudzie Pabianickiej, która podobnie jak Łódź z czasem zaczęła doświadczać kłopotów z zapewnieniem artykułów pierwszej potrzeby ${ }^{18}$. W latach późniejszych Sekcja Kobiet KONPB wysyłała także dzieci na kolonie letnie do Rudy Guzowskiej oraz bliżej nieokreślonych „dworów”"19.

lokalne organizacji. Komitet fundował głównie posiłki i odzież; w latach 1915-1918 współpracował z Komitetem Veveyowskim. W 1915 r. miasto odwiedzili przedstawiciele komitetu K. Hącia, hr Szołdrski i inni; D. Płygawko, Działalność Poznańskiego Komitetu Niesienia Pomocy Królestwu Polskiemu (1915-1918), [w:] Rola Wielkopolski w dziejach narodu polskiego, pod red. S. Kubiaka i L. Trzeciakowskiego, Poznań 1979, s. 287-288, 291; tejże, Polonia Devastata. Polonia i Amerykanie z pomoca dla Polski (1914-1918), Poznań 2003, s. 61.

15 GŁ nr 159, 25 VI 1915, s. 3; GŁ nr 161, 27 VI 1915 s. 3.

16 Wspomniany duchowny był silnie zaangażowany w różnego rodzaju akcje społeczne. W 1917 r. po tragicznym pożarze, w którym ok. 1000 mieszkańców Rzgowa straciło dach nad głową, pod przewodnictwem ks. Skowronka zawiązała się w Rzgowie Rada Opiekuńcza; P. Bieliński, 1905-2005. 100 lat Ochotniczej Straży Pożarnej w Rzgowie, ŁódźRzgów 2005, s. 50-51.

17 GŁ nr 184, 20 VII 1915, s. 2; NKŁ nr 196, 20 VII 1915, s. 1; NKŁ nr 212, 5 VIII 1915, s. 3; A. Stawiszyńska, Podłódzki Karlsbad czy letnisko dla mało wymagajacych? Ruda Pabianicka jako miejsce wypoczynku łodzian w latach I wojny światowej, [w:] Nieznane historie z Łodzi czasów Wielkiej Wojny, pod red. J.A. Daszyńskiej, Łódź 2016, s. 101.

18 Pozwolenie to było niezbędne, gdyż w związku z ogromnymi problemami aprowizacyjnymi istniał w Łodzi całkowity zakaz wywozu żywności z miasta. W Rudzie Pabianickiej, mimo nadal jej częściowo rolniczego charakteru, sytuacja też nie przedstawiała się najlepiej - istniały duże problemy w zaopatrywaniu się np. w mięso, które wcześniej sprowadzano głównie z Łodzi. Od czerwca 1915 r. obowiązywały tu karty chlebowe; APŁ, GKO, sygn. 75, k. 96, Pismo Sekcji Kobiet do GKO z dn. 28 VI 1915 r.; NKŁ nr 164, 17 VI 1915, s. 3; A. Stawiszyńska, Podłódzki Karlsbad..., s. 103-104.

19 APŁ, AmŁ, Wydział Opieki Społecznej (dalej: WOS), sygn. 17 845, k. 2. Streszczenie działalności Sekcji Kobiet KONPB od początku jej założenia. 
Letnie wyjazdy organizowało też Stowarzyszenie Kolonii Letnich dla Dzieci Chrześcijańskich i Żydowskich. Organizacja ta współpracowała z opisywaną wcześniej Sekcją Kobiet KONPB ${ }^{20}$. Podobnie jak inne tego typu organizacje otrzymywało ono pomoc m.in. z Komitetu Poznańskiego ${ }^{21}$.

Jedną z najważniejszych instytucji zajmujących się organizowaniem wspomnianych wyjazdów, z myślą o najmłodszych borykających się z problemami zdrowotnymi, był Komitet Kolonii Letnich dla biednych i słabowitych dzieci miasta Łodzi ${ }^{22}$, działający przy Łódzkim Chrześcijańskim Towarzystwie Dobroczynności (LChTD) 23. W 1915 r. podopieczni organizacji zostali wysłani do trzech miejscowości: Wiśniowej Góry, Okrąglika pod Zgierzem, gdzie korzystano z trzech domków zaoferowanych przez Wiesława Gerlicza ${ }^{24}$ oraz Orenic pod Piątkiem ${ }^{25}$. Do ostatniej miejscowości dzieci pojechały na zaproszenie ziemianek łęczyckich. Oferta złożona w ich imieniu przez p. Wernerową z Kraszna zakładała przyjęcie 68 dziewcząt i utrzymanie ich przez dwa turnusy pod warunkiem,

20 APŁ, GKO, sygn. 29, k. 122, Sprawozdanie z zebrania ws. organizacji kolonii letnich z dn. 26 VI 1915 r.

21 Pewna suma wpłynęła w czerwcu 1915 r. Zły stan dokumentu nie pozwala jednak na jej odczytanie, APŁ, GKO, sygn. 31, 238; Pismo zarządu Towarzystwa Kolonii Letnich dla dzieci chrześcijańskich i żydowskich do GKO z dn. 24 VI 1915 r.

22 Pierwsze wyjazdy dzieci łódzkich do Ciechocinka zorganizowano w $1891 \mathrm{r}$. z inicjatywy dr. Jana Wisłockiego. Opisywany Komitet działał od 1893 r. chociaż formalnie został zatwierdzony 6 lat później. Pierwszym przewodniczącym został dr J. Wisłocki, a w składzie zarządu znaleźli się m.in. lekarze H. Trenkner i E. Mittelstaedt. Przed wybuchem I wojny światowej organizacja wysyłała podopiecznych do miejscowości: Bronowice, Michałów, Dmosin, Gałków, Fabianka, Bryski czy Puczniew. Wyjazdy finansowała też m.in. rodzina Poznańskich, która w 1912 r. pokryła koszty pobytu dzieci swoich pracowników w podłódzkiej miejscowości Klinik; APŁ, Łódzkie Chrześcijańskie Towarzystwo Dobroczynności (dalej: ŁChTD), sygn.197, k. nlb, Ankieta Wydziału Opieki Państwowej nad Dzieckiem i Matką Ministerstwa Zdrowia Publicznego, Opieki Społecznej i Ochrony Pracy. Komitet kolonii letnich dla biednych i słabowitych dzieci przy ŁChTD; J. Sosnowska, Działalność socjalna i opiekuńczo-wychowawcza Łódzkiego Chrześcijańskiego Towarzystwa Dobroczynności (1885-1940), Łódź 2011, s. 292-297; J. Supady, Geneza „Przegladu Pediatrycznego” i Sekcji Pediatrycznej Łódzkiego Towarzystwa Lekarskiego, „Przegląd Pediatryczny" 2008, R. XXXVIII, nr 1, s. 2.

23 W zarządzie organizacji byli: przewodniczący Alfred Grohman, wiceprzewodnicząca Jadwiga Krasuska oraz członkowie: J. Galerowa, W. Wagner, J. Maybaum, W skład zarządu w 1915 r. po zmianach personalnych weszli też najbardziej znani łódzcy pedagodzy: Helena Miklaszewska. Wiktoria Macińska, Zofia Pętkowska, Wacław Kloss oraz Jan Czeraszkiewicz. Siedziba organizacji mieściła się przy ul. Dzielnej 2; APŁ, AmŁ, Wydział Statystyczny (dalej: WS), sygn. 23 574, k. 122, Komitet Kolonii Letnich dla biednych i słabowitych dzieci miasta Łodzi; J. Sosnowska, Działalność socjalna ..., s. 304-305.

24 Wiesław Gerlicz (1872-1933) - absolwent Instytutu Technologicznego w Petersburgu, dyrektor generalny Towarzystwa Łódzkich Wąskotorowych Elektrycznych Kolejek Dojazdowych. Znany działacz gospodarczy, poseł na Sejm RP w latach 1922-1927. Jeden z głównych założycieli i kierowników polskiego koncernu elektrotechnicznego „Siła i światło”, W. Źródlak, Łódzka podmiejska komunikacja tramwajowa, Łódź 2001, s. 28.

25 J. Sosnowska, Działalność socjalna..., s. 296, 304-305. 
że łódzka organizacja zadba o dostarczenie bielizny i pościeli. Natomiast w Okrągliku ze względu na to, że znajdujące się tam obiekty mogły pomieścić nie więcej niż 90 dzieci, zorganizowano kolonie wyłącznie dla biednych uczniów szkół średnich. Dzieci kwalifikowane do wyjazdów organizowanych przez ŁChTD otrzymywały specjalne karty. Ich opiekunowie byli zobligowani do stawienia się z nimi u wyznaczonych lekarzy. Ogółem latem 1915 r. na wyjazdy letnie wydano 3120 kart kwalifikacyjnych. $Z$ tego wyjechało jedynie 826 dzieci. Na niską liczbę dzieci zakwalifikowanych do wyjazdu $(26,47 \%)$ złożyło się kilka czynników. Większość, tj. 2284, nie wyjechała ze względu na brak miejsc w docelowych miejscowościach. Kolejnych 71 dzieci nie stawiło się na wymaganych badaniach lekarskich. Dwoje pozostało w mieście ze względu na stwierdzone u nich choroby zakaźne. Prace związane z organizowaniem wyjazdów obejmowały nie tylko poszukiwania odpowiednich miejsc, lecz także związane były z zapewnieniem dzieciom np. bielizny. W tym celu, w lokalu ofiarowanym przez L. Grohmana, stworzono szwalnię, w której pracowały opiekunki kolonijne pod nadzorem H. Knothowej. Transport do podłódzkich miejscowości odbywał się na koszt Łódzkich Elektrycznych Kolejek Dojazdowych ${ }^{26}$.

Latem 1916 r. organizacja planowała wysłanie podopiecznych do Wiśniowej Góry oraz Rudy Pabianickiej. W trosce o zdrowie dzieci przed wyjazdem zwrócono się do Wydziału Zdrowotności Publicznej Magistratu o informacje na temat sytuacji sanitarnej panującej w tychże letniskach ${ }^{27}$. Pomimo starań organizatorów podczas II turnusu, latem 1916 r., na letnisku w Wiśniowej Górze zanotowano kilka przypadków płonicy. W związku z tym konieczne było urządzenie tam domu izolacyjnego ${ }^{28}$.

Latem 1917 r., dzięki dotacji w wysokości 12,5 tys. mkp uzyskanych od Miejscowej Rady Opiekuńczej, ŁChTD zorganizowało ponownie wyjazd dla uczniów szkół średnich do Wiśniowej Góry. Ze względu na ciężką sytuację finansową każdy z uczestników musiał uiścić należność $12 \mathrm{mkp}$. Na zwolnienie z opłaty mogli liczyć wyłącznie najubożsi. Organizatorzy wyjazdu wyasygnowali większe kwoty na żywienie dzieci ${ }^{29}$. W $1918 \mathrm{r}$. ŁChTD nie wysłało podopiecznych na letni wypoczynek, gdyż do prac organizacyjnych przystąpiono zbyt późno ${ }^{30}$.

Organizacja przez okres swojej działalności poszukiwała darczyńców. Jednym z nich był Komitet Poznański, który w czerwcu 1915 r. zadeklarował przekazanie wsparcia finansowego w wysokości $40000 \mathrm{mk}^{31}$. Fundusze na zorganizowanie wyjazdów przekazała też m.in. fabryka L. Geyera. W sprawozdaniu kasowym ŁChTD z kwietnia 1915 r. znajdujemy wzmiankę o kwocie 32517,4 rb

\footnotetext{
26 APŁ, ŁChTD, sygn. 197, k. nlb, Sprawozdanie Komitetu Kolonii Letnich za 1915 r.

27 APŁ, AmŁ, WZP, sygn. 19 279, k. 24, Pismo Komitetu Kolonii Letnich dla słabowitych dzieci miasta Łodzi do Wydziału Zdrowotności Publicznej z dn. 6 VI 1916 r.

APŁ, ŁChTD, sygn. 197, k. nlb, Sprawozdanie Komitetu Kolonii Letnich za 1916 r.

J. Sosnowska, $d z$. cyt., s. 306-307.

APŁ, ŁChTD, sygn. 197, Pismo L. Grohmana do ŁChTD z dn. 16 VII 1918 r.

31 APŁ, GKO, sygn. 1, k. 593, Sprawozdanie GKO z dn. 11 VI 1915 r.
} 
pochodzącej z darów wspomnianej firmy ${ }^{32}$. Letnie wyjazdy dla podopiecznych ŁChTD w 1917 r. wsparli też kwotą 200 rb spadkobiercy Miny Konstadt ${ }^{33}$. W tym samym roku organizacja uzyskała też wsparcie ze strony Miejscowej Rady Opiekuńczej w wysokości 12,5 tysiąca mkp. W akcję wysyłania dzieci na kolonie letnie zaangażowani byli też lekarze, którzy np. dojeżdżali do chorych dzieci.

Tabela 2. Liczba podopiecznych LChTD wyslanych na wieś w $1915 \mathrm{r}$.

\begin{tabular}{|c|c|c|c|}
\hline Miejscowość & Chłopcy & Dziewczęta & Razem \\
\hline Okrąglik & 40 & 50 & 90 \\
\hline Orenice & - & 136 & 136 \\
\hline Wiśniowa Góra & 300 & 300 & 600 \\
\hline razem & 340 & 486 & 826 \\
\hline
\end{tabular}

Źródło: APŁ, ŁChTD, sygn. 197, k. nlb, Sprawozdanie Komitetu Kolonii Letnich za 1915 r.

Wiek wysłanych dzieci, podopiecznych ŁChTD, wahał się zazwyczaj między 7 a 16 rokiem życia. Największą grupę stanowiły tu dzieci w przedziale wiekowym od 8 do 11 lat.

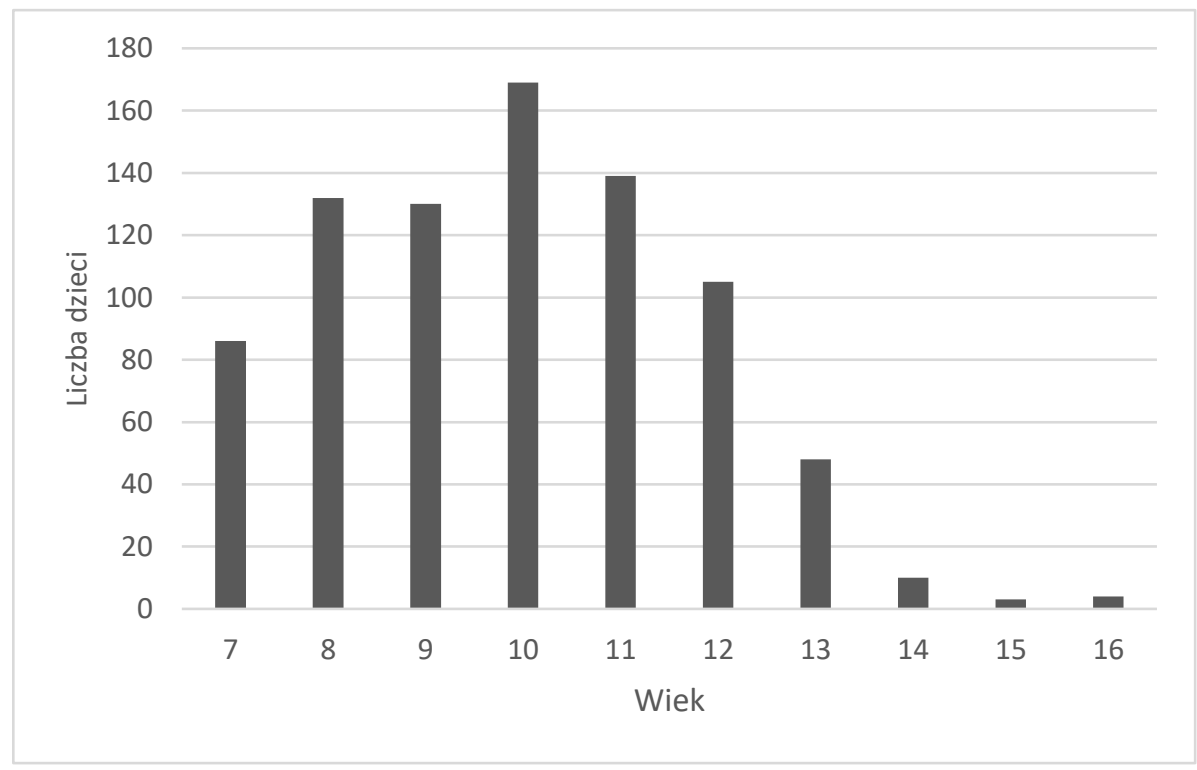

Wykres 1. Struktura wiekowa dzieci wysłanych na wieś przez ŁChTD w $1915 \mathrm{r}$. Źródło: APŁ, ŁChTD, sygn. 197, k. nlb, Dane statystyczne.

32 APL, ŁChTD, sygn. 32, k. 213, Sprawozdanie kasowe 9 IV 1915 r.

33 APŁ, ŁChTD, sygn. 33, k. 107, Sprawozdanie z posiedzenia zarządu ŁChTD z dn. 30 XI $1917 \mathrm{r}$. 
Akcję organizowania wyjazdów dzieci na wieś prowadziły też łódzkie parafie niemal wszystkich wyznań. Małych parafian, zwłaszcza tych, którzy byli sierotami, do gospodarstw swoich współwyznawców z podłódzkich miejscowości wysyłała m.in. parafia ewangelicko-augsburska pw. św. Mateusza ${ }^{34}$. Dzieci pozostające pod opieką Ewangelickiego Domu Sierot w Łodzi wyjeżdżały też do posiadanego przez placówkę gospodarstwa w Moszczenicy pod Strykowem. W 1917 r. zabudowa uległa poważnym zniszczeniom w wyniku pożaru ${ }^{35}$. Identyczną akcję pomocy dzieciom prowadził też Zarząd Ochron Mariawickich. Jednak ze względu na problemy z uzyskaniem funduszy miała ona zapewne niewielkie rozmiary ${ }^{36}$.

Wśród organizacji zajmujących się wysyłaniem dzieci łódzkich na wieś warto wspomnieć też o Komisji „Wieś dla dzieci” zawiązanej przez Łódzki Oddział Rady Opiekuńczej oraz Łódzką Miejscową Radę Opiekuńczą (ŁMRO). W 1917 r. instytucje zorganizowały specjalne zebranie w celu opracowania lepszego systemu wysyłania dzieci łódzkich na wieś. Wzięli w nim udział m.in. ks. Wincenty Tymieniecki oraz notariusz Kazimierz Rossman. Podczas narady zadecydowano o zorganizowaniu specjalnych objazdów okolicznych miejscowości i dworów przez trzyosobowe grupy członków ŁMRO. Postanowiono wcześniej powiadamiać miejscowych proboszczów, których zadaniem było przekazanie informacji na temat opisywanej akcji parafianom. Wspomniane delegacje odwiedziły m.in. miejscowości w powiecie kolskim, brzezińskim i łaskim ${ }^{37}$. Miejscowe Rady Opiekuńcze odpowiedzialne za pobyt dzieci otrzymały też specjalne instrukcje dotyczące dalszego postępowania. Po przyjeździe dzieci na miejsca należało zorganizować przejściowe schroniska, gdzie oczekiwały na nowych opiekunów. Rady zobowiązane były też do spisywania szczegółowych raportów, informujących o przekazaniu osób do danej rodziny. Jak podkreślano, dzieci w miejscu docelowym powinny uczęszczać do szkół. ŁMRO precyzowała też wymagania wobec tymczasowych opiekunów zaznaczając, że mali łodzianie mogą być przekazywani wyłącznie do takiej rodziny, co do której przedstawiciele miejscowych Rad Opiekuńczych „mają pewność, że jest moralnego prowadzenia się i że będzie opiekowała się serdecznie i szczerze dzieckiem". Podkreślano też rolę

34 H. Czembor, Dzieje parafii luterańskich w Łodzi do 1939 roku, [w:] Przeszłość przyszłości. $Z$ dziejów luteranizmu w Łodzi i regionie, pod red. B. Milerskiego i K. Woźniaka, Łódź 1998, s. 56.

35 W czerwcu 1917 r. Delegacja Niesienia Pomocy Biednym przyznała Zarządowi placówki 5000 mkp zaliczki na częściową odbudowę obiektu, APŁ, AmŁ, WOS, sygn. 17 931, k. 138, Protokół z posiedzenia Delegacji Niesienia Pomocy Biednym z dn. 19 VI 1917 r.

36 W przypadku ochron mariawickich wyjazdy te nie zawsze finansowane były przez miasto. W 1917 r. Delegacja Niesienia Pomocy Biednym odrzuciła podanie Zarządu w sprawie jednorazowej zapomogi na ten cel, APŁ, AmŁ, Rada Miejska (dalej: RM), sygn. 12 941, k. 136, Pismo Zarządu Ochronek Mariawickich do Delegacji Niesienia Pomocy Biednym z dn. 26 III 1918 r.; tamże, WOS, sygn. 17 931, k. 135, Protokół Delegacji Niesienia Pomocy Biednym z dn. 12 VI 1917 r.; NKŁ nr 135, 18 V 1915, s. 3.

GŁ nr 150, 3 VI 1917, s. 2. 
duchowieństwa w sprawowaniu należytej opieki ${ }^{38}$. W $1917 \mathrm{r}$. wysłano wraz z nauczycielkami 8 grup dzieci - łącznie 413 podopiecznych.

Oprócz wyjazdów letnich organizowano też pobyty długoterminowe, które w sprawozdaniu organizacji określano jako „wysyłanie dzieci na wieś na przeżywienie" ${ }^{\prime 3}$. W ramach ŁMRO pozostawało też „Towarzystwo Kolonii Letnich dla dzieci żydowskich miasta Łodzi" ${ }^{40}$, które w tym samym roku wysłało $385^{41}$ dzieci do miejscowości w sieradzkim, wieluńskim oraz na Kujawach. Jednocześnie odnotowano, że wspomniane wyjazdy przyniosły „dobre efekty”. Fundusze na zorganizowanie wyjazdów pochodziły ze składek członkowskich stowarzyszenia oraz zbiórek podczas organizowanych zabaw ${ }^{42}$. W kolejnym roku planowano wysłanie 700 dzieci w pięciu grupach począwszy od maja. Dzieci udawały się w podróż pod opieką wykwalifikowanych freblanek. Stowarzyszenie szacowało, że 4-tygodniowy pobyt dziecka na tychże koloniach kosztował 18,18 rb. Wyjazdy te, jak podkreślano w sprawozdaniu, przyniosły dobre efekty, zwłaszcza dla kondycji zdrowotnej podopiecznych ${ }^{43}$. Od sierpnia 1917 r. z Komisją współpracowała powołana przez Radę Opiekuńczą Miejscowa i Okręgową Sekcja Odzieży. Jej zadaniem było zaopatrywanie łódzkich dzieci wyjeżdżających na kolonie w ubrania. Sekcja posiadała własną szwalnię oraz składnicę odzieży przy ul. Piotrkowskiej $71^{44}$.

ŁMRO subsydiowała też Kolonie Letnie dla dzieci szkół średnich. W 1917 r. 140 jej podopiecznych wysłano do Wiśniowej Góry, gdzie korzystali z czterech domków przystosowanych do ich pobytu ${ }^{45}$.

38 GE nr 121, 4 V 1917, s. 4.

39 Główne cele organizacji: zakładanie schronisk, zaopatrywanie dzieci w niezbędną odzież, organizowanie półkolonii. W zarządzie Komisji zasiadali: K. Grabowska, doktorowa Brzozowska, p. Neumanowa, Wyganowska, Rossmanowa, W. Tymieniecki, J. Albrecht, A. Stamirowski, C. Chrzanowski, A.S. Łukomski; APŁ, AmŁ, WOS, sygn. 18 519, k. 12, Sprawozdanie z działalności ŁMRO i subsydiowanych przez nią instytucji za $1917 \mathrm{r}$.

40 Szerzej na temat działalności organizacji w latach przedwojennych: J. Sosnowska, Opieka nad dziećmi w Lodzi w latach I wojny światowej, Łódź 2017, s. 369-370.

$41 \mathrm{~W}$ innym dokumencie znajdujemy liczbę 403. Jako źródło finansowania wyjazdów podane są składki i ofiary zebrane podczas organizowanych zabaw; APŁ, AmŁ, WOS, sygn. 17939, k. 123, Pismo Towarzystwa Kolonii Letnich dla Dzieci Żydowskich miasta Łodzi do Wydziału Niesienia Pomocy Biednym z dn. 24 I 1916 r.

42 APŁ, AmŁ, WOS, sygn. 18 519, k. 18-19, Sprawozdanie z działalności ŁMRO i subsydiowanych przez nią instytucji za $1917 \mathrm{r}$.

43 APŁ, AmŁ, WOS, sygn. 17 939, k. 123, Pismo Towarzystwa Kolonii Letnich dla Dzieci Żydowskich miasta Łodzi do Wydziału Niesienia Pomocy Biednym z dn. 24 I 1916 r.

44 GŁ nr 196, 19 VII 1917, s. 3.

45 APŁ, AmŁ, WOS, sygn. 18 519, k. 18-19, Sprawozdanie z działalności ŁMRO i subsydiowanych przez nią instytucji za $1917 \mathrm{r}$. 
Letnie wyjazdy dla małych podopiecznych organizowało też Łódzkie Żydowskie Towarzystwo Dobroczynności ${ }^{46}$. Akcję tę z ramienia organizacji nadzorował Stefan Barciński ${ }^{47}$. W 1915 r. do Krzyżówki w okolicach Andrzejowa na 4-tygodniowy pobyt wysłało 120 dzieci $^{48}$.

Kwestie organizowania wyjazdów dzieci łódzkich często omawiane były np. przy okazji zjazdów okolicznych ziemianek, które deklarowały ile osób przyjąć może dana wieś czy majątek ${ }^{49}$.

Idea organizowania kolonii była też znana łódzkim filantropom, którzy czasem uwzględniali ten cel podczas spisywania ostatniej woli. W testamencie Natana Czamańskiego, znajdujemy zapis dotyczący Żydowskich Kolonii Letnich w Łodzi, na które zgodnie z wolą spadkodawcy miano przekazać $0,5 \%$ majątku ${ }^{50}$. Podobny zapis znalazł się także w testamencie innego lódzkiego filantropa, Maksymiliana Wuenschego ${ }^{51}$, który na rzecz Kolonii Letnich organizowanych przez ŁChTD zapisał kwotę $5000 \mathrm{rb}^{52}$.

Letnie wyjazdy małych łodzian sponsorowane były też przez poszczególne przedsiębiorstwa. Latem 1915 r. administracja fabryki L. Geyera wysłała 300 dzieci do pobliskiego Wiskitna. Pomoc ta dotyczyła jednak jedynie dzieci robotników zatrudnionych we wspomnianej fabryce. Dzieci zostały wysłane w dwóch równych grupach, osobno chłopcy i dziewczęta ${ }^{53}$. Ta sama fabryka latem $1916 \mathrm{r}$. wysłała 120 dzieci pracowników do podsieradzkiej Podłęży. Jak podawała prasa dzieci te miały pozostawać na wsi „do początku zimy”. Jednocześnie planowano wysłanie kolejnej grupy dzieci „,po żniwach” ${ }^{54}$.

46 Łódzkie Żydowskie Towarzystwo Dobroczynności - organizacja dobroczynna działająca w latach 1899-1939. W czasie wojny światowej wspierano podupadłych kupców, drobnych przedsiębiorców, wydawano pożyczki oraz zapomogi (np. pesachowe), K. Badziak, J. Walicki, Żydowskie organizacje społeczne w Lodzi (do 1939 roku), Łódź 2002, s. 93-98. GŁ nr 192, 28 VII 1915, s. 4.

GŁ nr 170, 6 VII 1915, s. 3.

GŁ nr 134, 17 V 1917, s. 6.

50 Natan Czamański (1873-1916) - długoletni dyrektor Towarzystwa Akcyjnego „S. Czamański”. W testamencie spisanym w styczniu 1914 r. uwzględnił wiele innych organizacji dobroczynnych niosących pomoc ludności żydowskiej oraz Towarzystwu Opieki nad Zwierzętami, Pogotowiu Ratunkowemu i Muzeum Nauki i Sztuki. Czamański w swojej ostatniej woli prosił, by jego pogrzeb był skromny. Zamiast kwiatów na grób, uczestnicy pogrzebu mieli wesprzeć finansowo którąś z organizacji wymienionych w jego testamencie; APŁ, ŁChTD, sygn. 79, k. nlb, Zapis Natana Czamańskiego, NKŁ, 6 I 1916, nr 5, s. 3. Maksymilian Wuensche w sporządzonym przez siebie testamencie zapisał większą część majątku w akcjach widzewskiej manufaktury na wybudowanie pawilonu gruźliczego przy szpitalu Anny Marii. Obiekt miał nosić imię jego wuja, Juliusza Kunitzera; T. Mogilnicki, 25-lecie szpitala Anny Marii w Lodzi 1905-1930, Łódź 1930, s. 75.

Biorąc pod uwagę, że wspomniana organizacja nie posiadała własnej ustawy, kwotę 5000 rb przejęło wstępnie ŁChTD, którego częścią były Kolonie; APŁ, ŁChTD, sygn. 80, k. 2, Pismo ŁChTD do GGW z dn. 26 XI 1916 r.; Tamże, k. 5, Pismo do Zarządu ŁChTD z dn. 16 X 1916 r.; tamże sygn. 33, Odpowiedź ŁChTD na pismo Magistratu z dn. 24 VIII 1917 r. GŁ nr 168, 4 VII 1915, s. 3. 
Na rzecz wyjazdów składano też specjalne datki. W maju 1916 r. „Godzina Polski" odnotowała przekazanie na ręce Prezydenta Policji Matthiasa von Oppena $20000 \mathrm{mk}$ z przeznaczeniem na zorganizowanie wyjazdów letnich dla dzieci ewangelickich. Za kwotę przekazaną przez niescharakteryzowane bliżej źródło z Niemiec wysłano 1000 dzieci do wsi Okup pod Łaskiem ${ }^{55}$. Pewne fundusze na wyjazdy letnie pochodziły też z największej akcji charytatywnej tego czasu - ogólnokrajowej kwesty „Ratujcie Dzieci” ${ }^{56}$. W 1917 r. z puli zebranych funduszy przekazano łącznie $24000 \mathrm{mkp}$ na letnie wyjazdy. Kwota ta została podzielona między stowarzyszenia organizujące wyjazdy dla dzieci różnych wyznań oraz Związek Harcerstwa Polskiego ${ }^{57}$.

Organizacje pragnące wysłać swoich podopiecznych na wieś występowały zwykle z prośbami do Delegacji Niesienia Pomocy Biednym o wsparcie finansowe. Pomoc ta nie zawsze była udzielana. Przykładowo w czerwcu 1917 r. odrzucono podanie zarządu Ochronek Mariawickich w sprawie uzyskania jednorazowej zapomogi na zorganizowanie letnich kolonii ${ }^{58}$. Magistrat natomiast udzielał dzieciom wyjeżdżającym na wieś jednorazowego wsparcia w wysokości $3 \mathrm{mkp}$, a od 1917 r. $5 \mathrm{mkp}^{59}$.

Wyjazdy dzieci łódzkich na wieś nie ograniczały się jedynie do wyjazdów letnich. Istniała też praktyka wysyłania dzieci na wakacje zimowe. Działalność taką prowadził m.in. Oddział Wysyłania Rodzin i Dzieci Robotników i Biednych działający przy Stowarzyszeniu Robotników Chrześcijan. Organizacja ta nie wysyłała jednak ubogich dzieci bezpośrednio do majątków ziemskich, ale wraz

55 „Godzina Polski” nr 127, 7 V 1916, s. 4.

56 Wielka Ogólnokrajowa Kwesta „Ratujcie Dzieci” - jedna z największych akcji dobroczynnych na ziemiach polskich w czasie I wojny. Zorganizowana po raz pierwszy w $1916 \mathrm{r}$. pod auspicjami Rady Głównej Opiekuńczej i kontynuowana w latach późniejszych. W działanie to zaangażowanych było 16590 kwestarzy. Darczyńcy otrzymywali zazwyczaj pamiątkowe znaczki. Pieniądze zbierano podczas specjalnie organizowanych imprez kulturalnych, odczytów, wystaw itp. Na terenie Łodzi w kwestę „Ratujcie Dzieci” zaangażowane były niemal wszystkie instytucje kulturalne i społeczne. Nad przebiegiem akcji w mieście czuwała komisja pod przewodnictwem ks. H. Przeździeckiego. W 1916 r. na terenie powiatu łódzkiego zebrano łącznie 9810 rb; M. Przeniosło, Organizacje samopomocy społecznej w Królestwie Polskim w latach I wojny światowej, „Niepodległość i Pamięć” 2011, R. XXXIII, s. 69-70; Sprawozdanie Kwesty „Ratujcie Dzieci”, Łódź 1916, s. 301, 314; A. Stawiszyńska, To byta orkiestra! „Ziemia Łódzka” 2013, nr 1, s. 4-5.

57 Ze wspomnianej sumy 12500 mkp przekazano na kolonie letnie dla młodzieży szkół średnich chrześcijan; $1500 \mathrm{mkp}$ dla dzieci ewangelickich; $7000 \mathrm{mkp}$ dla żydowskich. Związek Harcerstwa Polskiego uzyskał 3000 mkp; APŁ, AmŁ, RM, sygn. 12 999, k. 7, Sprawozdanie z podziału funduszy kwesty „Ratujcie Dzieci”.

58 Należy przypuszczać, że wyjazd mimo braku dotacji doszedł do skutku, gdyż w sprawozdaniu z marca 1918 r. znajdujemy wzmiankę o tym, że podopieczni spędzili miesiące letnie na koloniach na wsi; APŁ, AmŁ, WOS, sygn. 17 931, k. 3, Protokół Delegacji Niesienia Pomocy Biednym z dn. 12 VI 1917 r.; tamże, RM, sygn. 12 941, k. 137, Pismo Zarządu Ochron Mariawickich do Delegacji Niesienia Pomocy Biednym z dn. 26 III 1918 r.

59 APŁ, AmŁ, WOS, sygn.17.931, k. 138, Protokół posiedzenia Delegacji Niesienia Pomocy Biednym z dn. 19 VI $1917 \mathrm{r}$. 
z tamtejszymi ziemianami organizowała w czasie wojny w podłódzkich miejscowościach specjalne ochronki ${ }^{60}$. W grudniu 1915 r. wysłano 220 dzieci do miejscowości w kutnowskie i sieradzkie ${ }^{61}$. Akcję organizowania wyjazdów zimowych nadzorował m.in. ks. Wincenty Tymieniecki ${ }^{62}$.

Podobną informację znajdujemy w sprawozdaniu Oddziału Kobiet Komitetu Niesienia Pomocy Biednym Chorym Chrześcijanom działającym przy Delegacji Niesienia Pomocy Biednym ${ }^{63}$. Czytamy w nim o wysłaniu w grudniu 1915 r. 150 dzieci na wieś ${ }^{64}$. Długość pobytu została w korespondencji z Magistratem określona na „czas trwania wojny”. Wśród miejscowości docelowych były: Słupca, Kazimierz, Brzezia, Błaszki, Rusowo, Chyliny oraz Kalisz. Na miejsce były one odwożone przez członkinie organizacji ${ }^{5}$. Cześć z podopiecznych nie trafiła jednak do majątków ziemskich, lecz do bliżej niescharakteryzowanych schronisk w powiecie kutnowskim. Przed wyjazdem miały być one zaopatrzone

60 Stowarzyszenie Robotników Chrześcijan - organizacja powstała w 1904 r. przy parafii katolickiej pw. św. Krzyża. W latach 1907-1908 Stowarzyszenie liczyło ponad 100 tys. członków. Od 1910 r. SRCh przeniosło się do własnej siedziby przy ul. Przejazd 34. Głównym celem działalności organizacji było niesienie pomocy materialnej oraz rozwijanie życia kulturalnego wśród robotników. W czasie I wojny światowej SRCh prowadziło m.in.: 14 tanich kuchni, piekarnię oraz szwalnię zaopatrująca najuboższych mieszkańców miasta w odzież; W.L. Karwacki, Z zagadnień kultury $i$ oświaty robotniczej $w$ Lodzi $w$ latach 1905-1939, [w:] Włókniarze tódzcy. Monografia, pod red. E. Rosseta, Łódź 1966, s. 162; Ruch zawodowy w Polsce. Zarys dziejów, pod red. J. Kancewicza, Warszawa 1974, s. 170; A. Terlecki, Rzecz o społecznej solidarności w obliczu Wielkiej Wojny, [w:] Wielka Wojna o Ziemię Obiecaną. Operacja Łódzka 1914, pod red. P. Wernera, Łódź 2006, s. 31-32. NKŁ nr 336, 8 XII 1915, s. 2.

62 Wincenty Tymieniecki w czasie I wojny światowej współpracował z Głównym Komitetem Obywatelskim oraz Miejscową Radą Opiekuńczą. Prezes KONPB, współtworzył liczne instytucje charytatywne m.in. Towarzystwo Schronisk św. Stanisława Kostki, z których korzystało w 1917 r. 1500 dzieci. Z jego inicjatywy udało się wykupić przed zarekwirowaniem go przez władze okupacyjne dzwon Zygmunt wiszący w łódzkiej katedrze. Był prezesem Związku Macierzy Szkolnej, dążył do koordynacji wysiłków proboszczów łódzkich wobec okupanta, GŁ nr 295, 7 XI 1915, s. 2; Z. Czosnykowski, Biskup Wincenty Tymieniecki 1871-1934, [w:] Biskupi: W. Tymieniecki i K. Tomczak, pod red. E. i S. Zielkowskich, Łódź 1989, s. 20-22; T. Graliński, Ks. Dr Wincenty Tymieniecki. Biskup łódzki. Jego życie i działalność, Łódź 1935, s. 8-11; Pamiątka 25-lecia pracy kaptańskiej i społecznej ks. W. Tymienieckiego 1895-1920, Łódź 1920, s. 3, 11, 14.

63 W zarządzie wspomnianej organizacji znajdowały się: Józefa Pytlasińska, Maria Pałaszewska, Anna Knopfowa, Łucja Greenwood, pani Triebe, Elżbieta Daube, Jadwiga Łuba, Elfrieda Horak, Paulina Boehme, Bronisława Tymowska, Małgorzata Schmidt oraz dr Maria Tomaszewska; APŁ, AmŁ, WOS, sygn. 18 039, k. 83, Skład pracujących honorowo w Oddziale Kobiet Niesienia Pomocy Biednym Chorym Chrześcijanom. APŁ, AmŁ, WOS, sygn. 18 039, k. 81, Sprawozdanie Oddziału Kobiet Niesienia Pomocy Biednym Chorym Chrześcijanom za czas od 1 XII 1915 do 1 III 1916 r. APŁ, AmŁ, WOS, sygn. 18 356, k. 22-37, Listy dzieci wysyłanych jesienią 1915 r. 
w niezbędną bieliznę pościelową - sienniczki, kołderki i powłoczki. Cenę tegoż ekwipunku dla jednego dziecka wyceniano na $2 \mathrm{rb}^{66}$.

Podobne praktyki stosowała Sekcja Kobiet Chrześcijańskich KONPB. Jak podkreślano jednak w sprawozdaniu organizacji dzieci pozostające pod jej opieką nie zostały wysłane tam ,na czas wojny”, lecz na czas dokończenia nauki w rzemiośle, tj. na kilka kolejnych lat. Część podopiecznych (24 chłopców) miała je spędzić w Lądzie w guberni kaliskiej ${ }^{67}$.

Informacje na temat wysyłania podopiecznych na wieś znajdujemy też w aktach Łódzkiego Kuratorium Obywatelskiego roztaczającego opiekę nad rodzinami rezerwistów. Rozwiązanie to nie było jednak powszechnie stosowanym przez wspomnianą organizację. W 1917 r. spośród 1162 dzieci jedynie 69 przebywało na wsi. W liczbie tej dominowały dzieci katolickie (63). Dokumentacja nie wymienia nazw miejscowości ich pobytu. Niewykluczone, że podopieczni ci wysyłani byli do własnych krewnych ${ }^{68}$. Do podróży nakłaniano też kobiety pozostające pod opieką organizacji poprzez odmowę wydawania im zasiłków ${ }^{69}$.

Opisywane wyjazdy, mające na celu choćby czasową poprawę warunków bytowych dzieci łódzkich, służyły też zapewne celom mniej szlachetnym. W niektórych artykułach prasowych objaśniano proceder wykorzystywania wspomnianych dzieci do prac gospodarskich. W lipcu 1917 r. na łamach „Nowego Kuriera Łódzkiego" czytamy, że gospodarze przyjmujący do siebie dzieci zgłaszają liczne skargi dotyczące ich zachowania. Główne zarzuty dotyczyły kapryszenia przy jedzeniu oraz faktu, że dzieci „...nie zdradzają najmniejszej ochoty do pracy”. W artykule domagano się, aby odbyć spotkanie z matkami, które następnie miały wpłynąć na zachowanie dzieci ${ }^{70}$.

Niekiedy pojawiały się też idee organizowania dla dzieci wyjazdów dalszych niż te do podłódzkich miejscowości. W kwietniu 1917 r. kierownictwo Przytułku dla Dzieci Bezdomnych Wyznania Ewangelickiego zwróciło się do Wydziału Niesienia Pomocy Biednym miejscowego Magistratu z prośbą o pomoc w wyjednaniu u władz niemieckich zgody na wyjazd 20 chorych podopiecznych

66 APŁ, AmŁ, WOS, sygn. 18 355, k. 19, Pismo Oddziału Kobiet Niesienia Pomoc Biednym Chorym Chrześcijanom do Delegacji Niesienia Pomocy Biednym z dn. 11 X 1915 r.

67 APŁ, AmŁ, WOS, sygn. 18 039, k. 186, Sprawozdanie Sekcji Kobiet Chrześcijańskich za czas od 31 III do 1 VI $1916 \mathrm{r}$.

68 Na wieś wysłano też pięcioro dzieci ewangelickich i zaledwie jedno żydowskie, APŁ, AmŁ WOS, sygn. 17 924, k. 38, Sprawozdanie Patronatu na dziećmi rezerwistów pozbawionych rodzicielskiej opieki z dn. 8 X $1917 \mathrm{r}$.

69 APŁ, AmŁ, WOS, sygn. 17 938, k. 163-164, Odpowiedź Łódzkiego Kuratorium Obywatelskiego na odezwę z 9 IX $1916 \mathrm{r}$.

70 NKŁ nr 177,1 VII 1917, s. 1. 
na 4-tygodniową kurację do Ciechocinka, gdzie dzieci miały zostać zakwaterowane w miejscowym przytułku. Proszono też o sfinansowanie podróży. Nie wiadomo jednak czy wspomnianą zgodę uzyskano ${ }^{71}$.

W czasie trwania Wielkiej Wojny istniały też idee organizowania wyjazdów dzieci łódzkich na wieś o nieco innym charakterze. W grudniu 1915 r. na łamach „Gazety Łódzkiej” znajdujemy wzmiankę na temat działalności niejakiej pani Gutowskiej, pochodzącej z kaliskiego, która zwróciła się z prośbą o zabranie z Łodzi 70 dzieci, zwłaszcza ubogich sierot, w celu umieszczania ich u zamożnych włościan w okolicach Kalisza. Dzieci miały trafiać do rodzin, które utraciły wcześniej swoje własne dzieci. Nie wiadomo czy wspomniana akcja ,adopcyjna” była ostatecznie przeprowadzona ${ }^{72}$. Na terenie regionu łódzkiego notowano też przypadki przyjmowania całych rodzin przez okolicznych włościan. Latem 1916 r. ok. 50 rodzin łódzkich robotników znalazło schronienie w podkutnowskich majątkach ${ }^{73}$. Wyjazdy do podłódzkich miejscowości organizowały miejscowe organizacje skautowe. Oprócz typowych dla harcerstwa założeń miały one charakter zarobkowy. Skauci wyjeżdżający do miejscowości takich jak: Buczek, Marzenin czy Ruda Pabianicka zarabiali na swoje utrzymanie pracą na roli ${ }^{74}$. Podczas tego typu wyjazdów panował też zwyczaj samoopodatkowania się na rzecz młodszych kolegów, z myślą o zorganizowania im letniego wypoczynku w przyszłości. Każdy z pracujących na roli harcerzy przekazywał na ten cel od 1 do 2 rb za każdy przepracowany $\mathrm{w}$ ten sposób miesiąc ${ }^{75}$. Czasem wspomniane wyjazdy miejscowych skautów finansowane były ze składek osób prywatnych ${ }^{76}$.

W czasie I wojny światowej akcja wysyłania dzieci na wieś czy to na kolonie, czy też na dłuższe pobyty była powszechnie stosowaną formą pomocy na terenie całego Królestwa Polskiego. Podobnie jak w regionie łódzkim, działania te koordynowały miejscowe Rady Opiekuńcze oraz Komitety Ratunkowe. Nie brakowało też osób indywidualnych, chcących w ten sposób pomóc najmłodszym mieszkańcom miast silnie doświadczonym przez wojnę ${ }^{77}$. W związku z brakiem sprawozdań sporządzanych chociażby po powrocie dzieci do miasta trudno ocenić ich realny wkład w poprawę losu małych mieszkańców Łodzi. Sporadyczne dokumenty wspominaja jedynie o poprawie kondycji fizycznej. Dotyczyły one jednak kilkutygodniowych wyjazdów kolonijnych, nie zaś pobytów długotrwałych.

\footnotetext{
71 APŁ, Parafie i Stowarzyszenia z Terenu Łódzkiej Diecezji Ewangelicko-Augsburskiej. Zbiór szczątków zespołów, sygn. 47, k. nlb, Pismo Zarządu Przytułku dla Dzieci Bezdomnych Wyznania Ewangelickiego do Wydziału Niesienia Pomocy Biednym z dn. 16 IV $1917 \mathrm{r}$. 


\section{Summary}

\section{Organized Countryside Excursions as a Form of Support for Young Citizens of Lodz during the First World War}

Horrors of the First World War affected the life of all citizens of Lodz, especially the young ones. Victualing-related problems led to a phenomenon of hunger and numerous strictly connected diseases. Various charity organizations tried to help children from Lodz, for example by organizing countryside excursions for them. The children took part both in a few-week summer stays, as well as in a fewmonth visits to the countryside. One of the main aims set by the organizers was to improve the overall well-being of children by providing them with proper nutrition. Even though the children staying in the countryside were required to work and help farmers, some positive influence of the aforementioned stays was frequently indicated.

Keywords: First World War, Lodz, charity organizations, philanthropy

\section{Bibliografia}

Archiwalia

Archiwum Państwowe w Łodzi

Akta miasta Łodzi: Rada Miejska, Wydział Opieki Społecznej, Wydział Prezydialny, Wydział Statystyczny, Wydział Zdrowotności Publicznej

Główny Komitet Obywatelski

Łódzkie Chrześcijańskie Towarzystwo Dobroczynności

Parafie i Stowarzyszenia z Terenu Łódzkiej Diecezji Ewangelicko-Augsburskiej. Zbiór szczątków zespołów

Źródła drukowane

Sprawozdanie Kwesty ,,Ratujcie Dzieci”, Łódź 1916.

Prasa

"Gazeta Łódzka"

"Godzina Polski”

Jednodniówka na dochód Wielkiej Kwesty Ogólnokrajowej „Ratujcie Dzieci”, 11 VI 1916, Łódź 1916

„Nowy Kurier Łódzki”

„Rozwój”

Czasopisma

"Harcerstwo"

„Kultura i Wychowanie"

„Niepodległość i Pamięć"

„Przegląd Pediatryczny"

„Rocznik Łódzki”

„Zdrowie Publiczne”

„Ziemia Łódzka” 
Opracowania

Badziak K., Walicki J., Żydowskie organizacje społeczne w Łodzi (do 1939 roku), Łódź 2002. Bieliński P., 1905-2005. 100 lat Ochotniczej Straży Pożarnej w Rzgowie, Łódź-Rzgów 2005.

Czembor H., Dzieje parafii luterańskich w Łodzi do 1939 roku, [w:] Przeszłość przyszłości. Z dziejów luteranizmu w Łodzi i regionie, pod red. B. Milerskiego i K. Woźniaka, Łódź 1998.

Czosnykowski Z., Biskup Wincenty Tymieniecki 1871-1934, [w:] Biskupi: W. Tymieniecki i K. Tomczak, pod red. E. i S. Zielkowskich, Łódź 1989.

Graliński T., Ks. Dr Wincenty Tymieniecki. Biskup łódzki. Jego życie i działalność, Łódź 1935.

Jabłoński H., Z rozważań nad II RP. Pisma wybrane, Warszawa 1962.

Jałmużna T., Zakłady kształcenia nauczycieli w Łodzi w latach 1918-1988, Łódź 2001.

Jurek K., Lilijka i łódka. Historia harcerstwa łódzkiego do 1939 roku, Łódź 2006.

Jurek K., Łódzkie okręgi Polskiej Organizacji Skautowej w latach 1915-1916, „Harcerstwo” 1985, R. XXVII, nr 5.

Karwacki W.L., Z zagadnień kultury i oświaty robotniczej $w$ Lodzi w latach 1905-1939, [w:] Włókniarze tódzcy. Monografia, pod red. E. Rosseta, Łódź 1966.

Mogilnicki T., 25-lecie szpitala Anny Marii w Lodzi 1905-1930, Łódź 1930.

Pamiątka 25-lecia pracy kaptańskiej i społecznej ks. W. Tymienieckiego 1895-1920, Łódź 1920.

Płygawko D., Działalność Poznańskiego Komitetu Niesienia Pomocy Królestwu Polskiemu (1915-1918), [w:] Rola Wielkopolski w dziejach narodu polskiego, pod red. S. Kubiaka i L. Trzeciakowskiego, Poznań 1979.

Płygawko D., Polonia Devastata. Polonia i Amerykanie z pomoca dla Polski (1914-1918), Poznań 2003.

Przeniosło M., Organizacje samopomocy społecznej w Królestwie Polskim w latach I wojny światowej, „Niepodległość i Pamięć” 2011, R. XXXIII.

Ruch zawodowy w Polsce. Zarys dziejów, pod red. J. Kancewicza, Warszawa 1974.

Skarżyński M., Akcja pomocy społecznej w okresie działania GKO (3 VIII 1914-1 VII 1915), „ Rocznik Łódzki” 1975, R. XX.

Skład Komitetów Obywatelskich w dn. 1 V 1915 roku, Łódź, b.r.w.

Sosnowska J., Działalność socjalna i opiekuńczo-wychowawcza Łódzkiego Chrześcijańskiego Towarzystwa Dobroczynności (1885-1940), Łódź 2011.

Sosnowska J., Opieka nad dziećmi w Łodzi w latach I wojny światowej, Łódź 2017.

Stawiszyńska A., Łódź w latach I wojny światowej, Oświęcim 2016.

Stawiszyńska A., Podłódzki Karlsbad czy letnisko dla mało wymagających? Ruda Pabianicka jako miejsce wypoczynku łodzian w latach I wojny światowej, [w:] Nieznane historie z Łodzi czasów Wielkiej Wojny, pod red. J.A. Daszyńskiej, Łódź 2016.

Stawiszyńska A., Realia życia dzieci łódzkich w czasie Wielkiej Wojny. Wybrane zagadnienia, „Kultura i Wychowanie” 2014, t. VIII.

Stawiszyńska A., To była orkiestra!, „Ziemia Łódzka” 2013, nr 1.

Supady J., Geneza „Przegladu” Pediatrycznego” i Sekcji Pediatrycznej Łódzkiego Towarzystwa Lekarskiego, „Przegląd Pediatryczny” 2008, R. XXXVIII, nr 1.

Supady J., Powstanie i rozwój kolonii letnich dla dzieci w Lodzi na przetomie XIX i XX wieku, „Zdrowie Publiczne” 1977, t. LXXXVIII, nr 3.

Szymański M.J., Wojenny chleb (nie)powszedni. Łódź w niemieckim systemie zaopatrzenia $w$ produkty $i$ surowce zbożowe na terenie okupowanego Królestwa Polskiego podczas I wojny światowej, [w:] Operacja Łódzka. Zapomniany fakt I wojny światowej, pod red. J.A. Daszyńskiej, Łódź 2011.

Terlecki A., Rzecz o społecznej solidarności w obliczu Wielkiej Wojny, [w:] Wielka Wojna o Ziemie Obiecaną. Operacja Łódzka 1914, pod red. P. Wernera, Łódź 2006.

Źródlak W., Łódzka podmiejska komunikacja tramwajowa, Łódź 2001. 